\title{
The role of land-use history in major invasions by woody plant species in the northeastern North American landscape
}

\author{
Eric S. Mosher · John A. Silander Jr. • \\ Andrew M. Latimer
}

Received: 21 April 2008/Accepted: 16 December 2008/Published online: 10 January 2009

(C) The Author(s) 2009. This article is published with open access at Springerlink.com

\begin{abstract}
Land-use history as a predictor of invasive alien plant distributions has received little study, especially across large spatial and temporal scales. Here we evaluate the importance of land-use history and other environmental characteristics as predictors of the distributions of a suite important invasive woody plant species in the northeastern United States. Using historical aerial photographs, we delineated 69 years (1934-2003) of land-use change across a typically heterogeneous $95 \mathrm{~km}^{2}$ landscape. We randomly surveyed over 500 sites for six invasive plant species. We found that land use history patterns strongly affected presence and abundance of the invasive plants as a group, but affected some species more than others. Generally, past agricultural use favored invasive
\end{abstract}

Electronic supplementary material The online version of this article (doi:10.1007/s10530-008-9418-8) contains supplementary material, which is available to authorized users.

E. S. Mosher

Connecticut River Coastal Conservation District, Inc.,

27 Washington Street, Middletown, CT 06457, USA

J. A. Silander Jr.

Department of Ecology and Evolutionary Biology, University of Connecticut, 75 North Eagleville Road, Unit 3043, Storrs, CT, USA

\section{A. M. Latimer $(\square)$}

Department of Plant Sciences, University of California, One Shields Avenue, Davis, CA 95616, USA

e-mail: amlatimer@ucdavis.edu species, whereas intact forest blocks discouraged them. Current land-use trends toward residential/commercial development favor disturbance-adapted species like Celastrus orbiculatus (asiatic bittersweet) and will probably slow the spread of post-agricultural specialists such as Berberis thunbergii (Japanese barberry).

Keywords Land use history - Remote sensing · Invasive species - Agricultural land use . Berberis thunbergii $\cdot$ Celastrus orbiculatus

\section{Introduction}

Land-use history has been shown to be a key factor driving vegetation patterns and community dynamics, including colonization and invasion by exotic species (DeGasperis and Motzkin 2007; Gerhardt and Foster 2002; Hall et al. 2002; Motzkin et al. 1999; Singleton et al. 2001). Nonetheless, few studies have directly addressed the relationships between land-use history and exotic plant invasions. Those studies that have examined these relationships have tended to focus narrowly on specific habitat types-for example old fields, secondary tropical forests and temperate forests-without comparing multiple land-use patterns across heterogeneous landscapes (Bartuszevige et al. 2006; Hobbs 2001; Kulmatiski et al. 2006; Lundgren et al. 2004; Meiners et al. 2002; Pascarella et al. 2000). In highly altered landscapes, land-use 
history is arguably the dominant factor in disturbance regimes (De Blois et al. 2002; Foster et al. 1998), so we might expect that different patterns of land-use change will create distinct "windows of opportunity" for invasion (Hobbs 2000; With 2002), which should affect distributions of invasive plants. Indeed, several recent papers have pointed to the over-riding importance of land-use history in understanding and predicting the distribution and abundance of plant species in general (Bellemare et al. 2002; Donohue et al. 2000; Dupre and Ehrlen 2002; Verheyen et al. 2003a, b; Vila et al. 2003), and of individual invasive species (DeGasperis and Motzkin 2007). But to our knowledge, no comprehensive study has examined how variation in land-use patterns across a heterogeneous landscape influences the presence and abundance of a suite of important invasive species.

The stochastic nature of biological invasions (Mack 2000), the multiplicity of factors with the potential to affect the invasion process (Aragon and Morales 2003) and the dynamic nature of landscape processes (De Blois et al. 2002) make studying the invasive plant response to land-use quite challenging. To determine the relative importance of land-use history among these many factors, it is necessary to investigate at appropriate spatial and temporal scales. To do so requires a spatial scale that encompasses the full range of land-use patterns typical to a given region and a temporal scale that brackets the time frames of both the key invasion processes and the pertinent land-use changes. A comprehensive study that effectively encompasses these spatial and temporal complexities would thus provide critical insight into the landscapelevel pattern and process of invasion.

To evaluate the relationships between land-use history and plant invasions, we chose to investigate the distribution of a suite of woody invasive species across a heterogeneous landscape in southern New England, USA. This region has undergone an intensive $300+$ year period of land-use change, including large-scale clearing of forests for agriculture through the mid $1800 \mathrm{~s}$, followed by more than a 100 years of gradual agricultural abandonment and natural reforestation (Cronon 1983; Foster 1992). At present, the predominant post-agricultural temperate forest of the region is being altered by a new land-use trend: accelerated suburban and commercial development (CLEAR 2004; Thorson 2002). Thus, as an area for study, southern New England combines a history of intensive anthropogenic activity and a major shift in land-use trends during the last half century with concurrent increases in the prevalence and distribution of invasive plant species.

We focused on woody invasive plants for several reasons. First, woody shrubs and vines are the most widespread and abundant terrestrial invasive plants across southern New England (Herron et al. 2007; Mehrhoff et al. 2003). Second, they are the most common invaders of "minimally managed" habitats, a distinction that is the basis for the definition of invasiveness used by the Invasive Plant Atlas of New England (Mehrhoff et al. 2003). Third, recent studies in the region have demonstrated linkages between woody plant invasions and land-use history patterns (Lundgren et al. 2004). Finally, the major woody invasive plants of southern New England share certain ecological and historical commonalities: their fruits are bird dispersed; they were introduced to US for horticultural purposes [for an example of the relationship between invasive spread and horticultural usage, see (Silander and Klepeis 1999)]; the first herbarium specimens reporting their naturalizations in southern New England date from 1909 to 1920; and they were first recognized as problematic species after the middle of the 20th century (Mehrhoff et al. 2003). Thus, these species made the transition from naturalization to invasive spread (Richardson et al. 2000) sometime within the last half century, during the time period we bracket in this study.

Our goal was to conduct a landscape-scale sampling for the presence and abundance of woody invasive plants, stratified across different patterns of land-use change. To accomplish this, we developed a digital, geo-referenced method for quantifying land-use change across a representative, but heterogeneous, $95 \mathrm{~km}^{2}$ landscape, using four time intervals dating back to 1934. Prior to this study there was no consistently compiled, spatially referenced land-use change record covering the study area over the relevant time period. In order to sample land-use change comprehensively over space and time, we used this detailed record to design a randomized study, stratified by current land use and land use history class.

We addressed the following questions: are there statistically significant relationships between different land-use histories and the distributions of woody invasive species in our southern New England landscape? If so, how strong are these relationships? What 
other factors are important in determining the distributions of woody invasive plants? And finally, given the continuing trends in land-use change across the region, can we provide management guidance by identifying which species, and which kinds of land use, are likely to pose a greater invasion threat in the future?

\section{Methods}

\section{Study landscape}

The study landscape encompasses nearly $100 \mathrm{~km}^{2}$ of land centered on the southern portion of the Meshomasic State Forest in central Connecticut, US (Fig. 1). The Meshomasic State Forest was founded in January 1903, making it the oldest state forest in the New England region. In the mid-1800s, much of the landscape was used for agriculture. Some of the study landscape has been in continuous cultivation, while other areas have been cultivated periodically, but most of the marginally productive areas had been abandoned by the early 19th century. Many rocky and steep areas within the study landscape were never plowed and were used only as woodlot. From the mid-1800s to the early 1900 s much of the agricultural landscape in New England was abandoned and began reverting to natural, minimally managed forest (Foster 1992). The Meshomasic landscape offers a good example of this reforestation, one that was made more permanent with the founding of the state forest.

Elevation across the landscape varies from $9 \mathrm{~m}$ near the Connecticut River to $274 \mathrm{~m}$ at the top of Meshomasic Mountain. The majority of soils ( $>80 \%$ ) are loamy to coarse-loamy in texture and are members of the Dystrudept great group (order = Inceptisols). Other soil types include wetland soils of the Endoaquept and Humaquept great groups

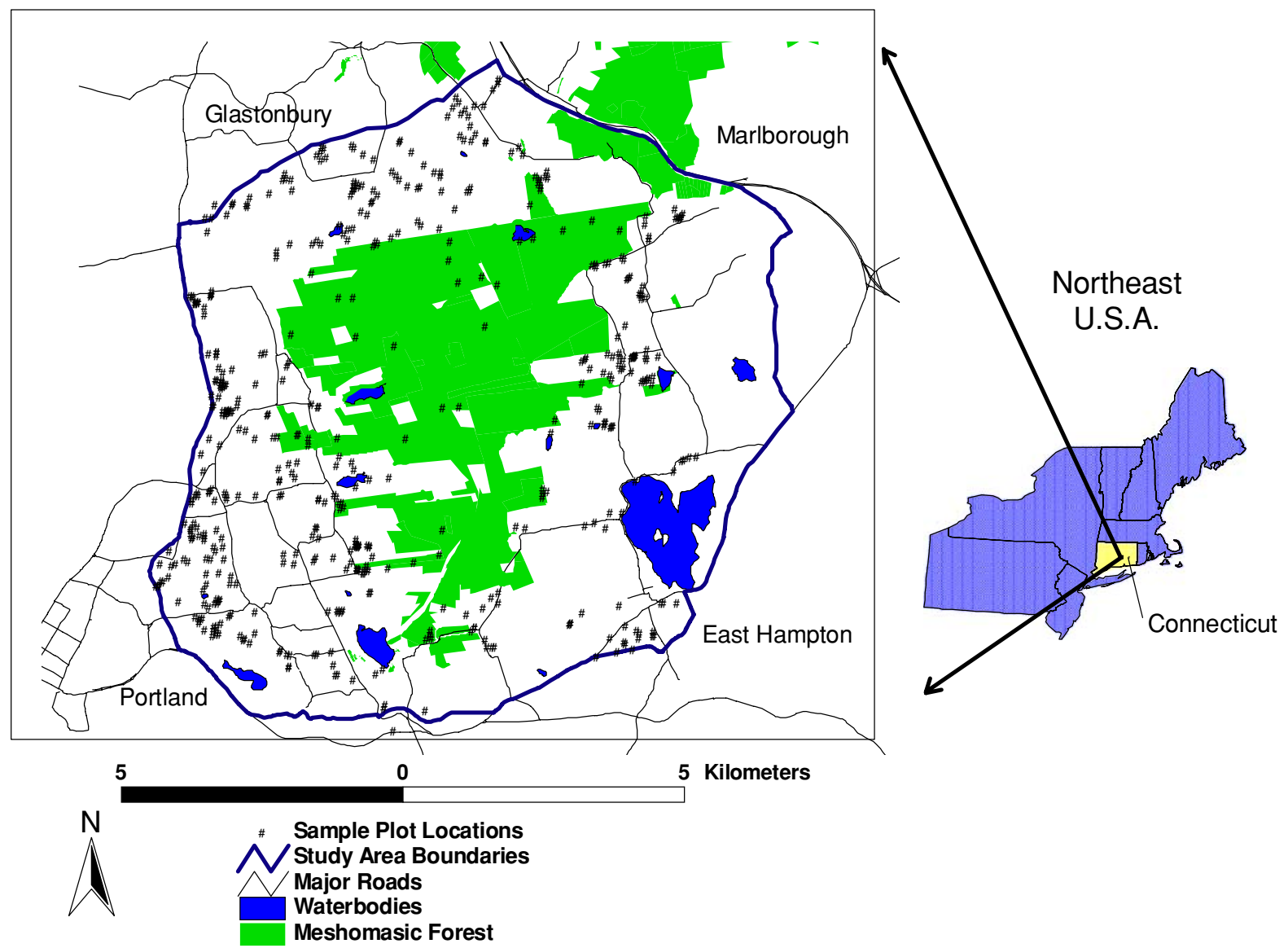

Fig. 1 Study landscape of the Meshomasic State Forest (shaded green areas) and surrounding areas, with sample plot locations (black dots) 
Table 1 Attributes of focal invasive species

\begin{tabular}{lllll}
\hline Study species & $\begin{array}{l}\text { Year of 1st introduction } \\
\text { to the US }\end{array}$ & $\begin{array}{l}\text { Year of 1st } \\
\text { herbarium specimen } \\
\text { in Connecticut }\end{array}$ & $\begin{array}{l}\text { Year of 1st } \\
\text { herbarium specimen } \\
\text { from study counties }\end{array}$ & $\begin{array}{l}\text { Growth form } \\
\text { and size }\end{array}$ \\
\hline $\begin{array}{l}\text { Berberis thunbergii } \\
\text { Celastrus orbiculatus }\end{array}$ & 1875 & 1920 & 1951 & Thorny shrub-0.5-2.4 m \\
Elaeagnus umbellata & 1830 & 1916 & 1954 & Woody vine-up to 17.3 m \\
Euonymus alata & 1860 & 1922 & 1940 & Shrub to small tree-3.7-6.0 m \\
Lonicera morrowii & 1875 & 1911 & 1959 & Shrub-4.5-6.0 m \\
Rosa Muliflora & 1886 & 1915 & 1915 & Shrub-up to 2.5 m \\
\hline All & 1909 & 1953 & Thorny shrub-up to 4.5 m \\
\hline
\end{tabular}

All data are from the Invasive Plant Atlas of New England's Catalogue of Species and Records Database (Mehrhoff et al. 2003)

(order $=$ Inceptisols), and sandy Udorthents (order $=$ Entisols). The bedrock materials are primarily gneisses and schists, with limited amounts of quartzite, brownstone and amphibolite. Thin glacial till is the dominant surficial material, covering approximately $80 \%$ of the landscape. Thick till, sand and gravel account for most of the remainder.

Today, the state forest's irregular outline is filled in by privately owned forest parcels, which in turn are surrounded by a fringe of mixed agricultural and residential land use. Moving outward from this fringe, the landscape becomes more densely developed. Thus, in a relatively compact area, this landscape spans the range of current and historical land-use patterns typical of much of the northeastern US.

Target invasive species

We sampled the landscape for the presence and abundance of six woody invasive plants: Berberis thunbergii DC (Japanese barberry), Celastrus orbiculatus Thunb. (oriental bittersweet), Elaeagnus umbellata Thunb. (autumn olive), Euonymus alata (Thunb.) Siebold (winged euonymus), Lonicera morrowii Gray (Morrow's honeysuckle), and Rosa multiflora Thunb. Ex Murr. (multiflora rose). These species have been identified as the most common invasive woody plants throughout southern New England (Mehrhoff et al. 2003); however, we had no prior knowledge as to how common they were within the study landscape. These species all tend to be bird-dispersed, but they vary otherwise in life form and life history traits (Herron et al. 2007). Since, relatively little is known of the basic biology and ecology of these species, one of our goals was to acquire knowledge that would have some direct practical application. Table 1 provides a comparison of the species' dates of introduction, growth forms and sizes.

Processing historical aerial photographs

In order to reconstruct a comprehensive record of land-use change, we acquired complete historical aerial photographic series of the study landscape from 1991, 1970, 1951, and 1934. Additionally, we conducted on-the-ground surveys in 2003 and cross referenced our land-use characterizations from those surveys with a set of panchromatic year-2000 IKONOS satellite images. In this way, we were able to evaluate land-use change over a 69-year interval (1934-2003) using five well-spaced time steps.

The 1991 images (Digital Ortho Quarter QuadsCT State Plane, NAD 83, feet) served as the baseline for geo-referencing all of the remaining aerial photographs. This was done using the geometric correction module in ERDAS Imagine 8.5. For geocorrection, we used a minimum of 15 ground control points (consisting of temporally stable features such as intersections, dams and buildings), a second order polynomial transformation and an RMS of less than ten. Whenever possible, the same ground control points were utilized across time frames. The resulting corrected images all had a pixel size of three feet - the same resolution as the 1991 DOQQs (Al-tahir and Ali 2004). Once all of the images were geo-referenced, we utilized the mosaic tool in ERDAS Imagine 8.5 to create a single image of the study landscape for each of the time steps (see Fig. S1a-d in the Supplementary Material). 
Table 2 Land use change categories

\begin{tabular}{ll}
\hline LULC change categories & Detailed LULC change categories \\
\hline No change (159) & Forests-no change (69) \\
& Cultivated fields—no change (30) \\
& Pasture/Meadow-no change (23) \\
& Residential/commercial—no change (37) \\
Agricultural fields reverted to forest (143) & Abandoned fields reverted to forest (28) \\
& Cultivated fields reverted to forest (39) \\
& Pasture/Meadow reverted to forest (76) \\
& Abandoned fields as of 2003 (39) \\
Abandoned fields as of 2003 (39) & Forest to residential/commercial (25) \\
Residential/commercial development (166) & Cultivated fields to residential/commercial (47) \\
& Pasture/Meadow to residential/commercial (62) \\
& Abandoned fields to residential/commercial (32) \\
\hline
\end{tabular}

Number of sample locations falling in each category is shown in parentheses
69 year period), Abandoned Fields as of 2003, Agricultural Fields Reverted to Forest and Residential/ Commercial Development (see Table 2). We then further refined these large categories by breaking them into 12 more finely differentiated LULC change categories ("Detailed LULC Change"). By merging the 12 sets of polygons representing these distinct categories of LULC change, we created a single land-use change mosaic for the entire study landscape (see Fig. S3).

Random point generation and sampling procedure

We converted the completed land-use change mosaic into a raster layer with 13 different values: the 12 different LULC Change categories, plus a null category for areas that had not been digitized. Then, using the accuracy assessment module in Erdas Imagine 8.5, we generated 50 random points in each of the 13 categories. We navigated using GPS to within $2 \mathrm{~m}$ of each point before establishing a plot for sampling. Points located on private property necessitated that we obtain landowner permission prior to sampling. Despite restricted access to some private areas, we were able to sample 507 of the 650 randomly generated points. We utilized the Invasive Plant Atlas of New England's plot protocols (Mehrhoff et al. 2003) for structuring our data collection, including the use of circular plots (10-m radius) and the collection of a suite of categorical data types concerning the plot environment and the status of invasive plants. Target species abundances were scored using six ordinal classes (single, less than 20, 20-99, 100-999, 1,000+) (see Table S1). 
We utilized our current LULC observations to complete the final LULC Change category of each plot. We utilized available GIS layers of the study landscape (soil types, bedrock types, DEM, etc.) to obtain additional environmental data for each sample plot. Also, we used the mosaic images (including the 2000 IKONOS images) in ArcView 3.2 to make measurements from our sample plots to the nearest Vegetation Edge, Road and Building (see Table S2).

\section{Statistical analysis}

All statistical analyses were performed using the S-PLUS $^{\circledR} 6.1$ statistical software package. We utilized Pearson's chi-square tests $(2 \times 4$ contingency tables) to determine if levels of invasive species frequency were significantly different when compared across the four Grouped LULC Change patterns. Because the species abundance data are ordinal, we employed the Wilcoxon Rank Sum Test (Snedecor and Cochran 1989) to compare the abundance scores of invasive species associated with the categorical values of the following variables: LULC Change, Canopy Closure and Time of Agricultural Abandonment.

In order to evaluate the relative contributions of the variables toward explaining woody invasive presence/ absence and abundance, we created generalized linear models (GLMs) using a stepwise regression approach with Akaike's information criterion (AIC) as the determinant of inclusion in each model (Venables and Ripley 2002). In constructing the GLMs, we used the categorical variables Grouped LULC Change, Canopy Closure, Habitat Class, and LULC Features, as well as continuous variables such as distance to a vegetation edge and length of roads within a bugger (see Table S3 for the complete set of variables considered for the GLMs). We used logistic regressions for modeling presence/absence data and Poisson log-linear GLMs for modeling invasive species abundance. To determine whether spatial autocorrelation could be influencing the results in the regression analysis, we used the program Spatial Analysis for Macroecology to calculate Moran's I values and their statistical significance for pairs of points in a range of distance classes (Rangel et al. 2006).

\section{Results}

Invasive species frequency and abundance

We sampled a total of 507 plots, between July 12 and October 16 of 2003 (see Fig. 1). At least one of the target woody invasive species was present in $55.4 \%$ (288/507) of the randomly established plots, with the following frequencies for the individual target species: C. orbiculatus $36.7 \%$, Rosa multiflora $31.2 \%$, B. thunbergii $27.6 \%$, Lonicera morrowii $25.8 \%$, Euonymus alatus $7.1 \%$, and Euonymus umbellata $2.0 \%$. Due to their lower frequencies, we used the results for E. alata and E. umbellata only as part of our combined species analyses.

Table 3 gives the frequency of target species within the four Grouped LULC Change categories. Chi-square contingency table analysis shows that these frequencies are highly significantly different across the categories for each of the target species.

Table 3 Target species frequency by grouped LULC change categories

\begin{tabular}{|c|c|c|c|c|c|}
\hline Species & $\begin{array}{l}\text { Recently } \\
\text { abandoned } \\
\text { fields } \\
(2003)(\%)\end{array}$ & $\begin{array}{l}\text { Reforested } \\
\text { agricultural } \\
\text { fields }(\%)\end{array}$ & $\begin{array}{l}\text { Residential/ } \\
\text { commercial } \\
\text { development } \\
(\%)\end{array}$ & $\begin{array}{l}\text { No change } \\
(\%)\end{array}$ & $\begin{array}{l}\text { Pearson's Chi } \\
\text { square }\end{array}$ \\
\hline Berberis thunbergii & 30.8 & 53.1 & 18.1 & 13.8 & $\chi^{2}=69.49, P<0.0001$ \\
\hline Celastrus orbiculatus & 76.9 & 42.6 & 39.2 & 18.8 & $\chi^{2}=51.55, P<0.0001$ \\
\hline Lonicera morrowii & 66.7 & 43.4 & 19.3 & 6.9 & $\chi^{2}=90.26, P<0.0001$ \\
\hline Rosa multiflora & 71.8 & 47.6 & 21.1 & 17.0 & $\chi^{2}=70.69, P<0.0001$ \\
\hline All species: average & 44.4 & 33.4 & 18.7 & 11.1 & $\begin{array}{l}\chi^{2}=203.24 \\
P<0.0001\end{array}$ \\
\hline All species: combined & 89.7 & 71.8 & 55.1 & 30.8 & $\chi^{2}=72.79, P<0.0001$ \\
\hline
\end{tabular}

$\chi^{2}$ analysis indicates that the frequencies of target species are significantly different across the grouped LULC change categories 
The average frequency results (for all six target species combined) reveal a distinct pattern: Abandoned Fields in $2003(44.4 \%)>$ Fields Reverted to Forest before $2003(33.4 \%)>$ Developed to Residential/Commercial $(18.7 \%)>$ LULC No Change (11.1\%). Interestingly, this pattern does not hold for B. thunbergii; its frequency was greater in Fields Reverted to Forest before 2003 (53.1\%) than Abandoned Fields in 2003 (30.8\%).

Comparing the combined invasive abundance of all target species across the Grouped LULC Change categories reinforces the pattern revealed in Table 3 : land use change histories are consistently and statistically significantly ranked with respect to invasive species abundance. Abundance of invasive species was significantly greater in Abandoned Fields as of 2003 than in Agricultural Fields Reverted to Forest (Wilcoxon Rank Sum test, $P=0.005$ ). Agricultural Fields Reverted to Forest had greater invasive abundance than Residential/Commercial Development $(P<0.0001)$, which in turn had greater invasive abundance than the LULC No Change category $(P<0.0001)$.

Using rank sum tests to compare invasive species abundances across the 12 original LULC change categories adds more resolution to this invasion hierarchy and points out further differences among species (see Table 4). Abandoned Fields in 2003 ranked highest in invasive abundance for all of the species except $B$. thunbergii. In the case of $B$. thunbergii, the three categories representing pre-2003 reversion of agricultural fields to forest all ranked ahead of Abandoned Fields in 2003. Persistent residential use (Residential/Commercial No Change) was associated with higher invasive abundance than the other three No Change categories (Forest No Change, Cultivated Fields No Change and Pasture/ Meadows No Change). Lastly, consistently plowed areas (Cultivated Fields No Change) and intact forest (Forests No Change) were consistently at the bottom of the rankings, never rising above the 10th rank in invasive species abundance.

The evident relationship between post-agricultural land-use categories and woody invasion prompted us to evaluate invasive abundance with respect to time of abandonment. For all of the species combined, and for three of the four main target species, invasive abundance decreased as time since plot abandonment increased (see Table 5). The time of abandonment results for one species, B. thunbergii, were quite different-the two oldest categories (1951-1st and 1934-2nd) were associated with the highest levels of abundance.

Using Rank Sum tests to compare the abundance of the combined target species revealed contrasts across canopy closure levels: target invasive species were more abundant in plots with $51-75 \%$ canopy closure than $26-50 \%$ canopy closure $(P<0.001)$; 26-50\% canopy closure had greater invasive abundance than $76-100 \%(P=0.003)$; and $76-100 \%$ had greater abundance than $0-25 \%(P<0.0001)$.

Regression modeling results

Table 6 shows the results from five stepwise regression models constructed to explain invasive species abundance patterns. The models included from 17 to 24 variables, with resulting $r$-square values ranging from 0.41 to 0.55 . Because there was spatial structure in the initial model residuals, we added $x$ and $y$ coordinates for each point into the regression, as a simple way of representing spatial trend in the data. After including these variables, spatial autocorrelation in the residuals was eliminated completely for one species (C. orbiculatus), and reduced to negligible levels (Moran's $I$ values of 0.02-0.03) in the shortest distance class $(<100 \mathrm{~m})$ for the other three species.

In a separate analysis, we found that land use history and environmental factors remained broadly significant in spatially explicit models of presence/absence of the four most common species (Latimer et al. 2009).

Grouped LULC Change ranked as either the 1st or 2nd most important (in terms of variance explained) explanatory variable in all five models and Canopy Closure ranked 1 st or 2 nd in four out of the five models. Distance to a Vegetation Edge ranked as an important explanatory variable in four out of five models. Heavily Managed Plots, the LULC features of individual time steps, and $X / Y$ coordinates were ranked among the most important variables multiple times (see Tables S5, S6). The $X / Y$ coordinates give an approximation of the contribution of spatial location towards explaining variation in abundance patterns.

\section{Discussion}

Our results indicate that land-use history plays an important role in structuring the extent, pattern, and 
Table 4 Ranking abundance of invasive species by the 12 detailed LULC change categories

\begin{tabular}{|c|c|c|c|c|c|c|c|c|c|c|}
\hline $\begin{array}{l}\text { Abundance } \\
\text { rank }\end{array}$ & All species & & $\begin{array}{l}\text { Berberis } \\
\text { thunbergii }\end{array}$ & & $\begin{array}{l}\text { Celastrus } \\
\text { orbiculatus }\end{array}$ & & $\begin{array}{l}\text { Lonicera } \\
\text { morrowii }\end{array}$ & & Rosa multiflora & \\
\hline 1 & $\begin{array}{l}\text { Abandoned } \\
2003\end{array}$ & $\mathrm{~A}$ & Pasture to forest & A & $\begin{array}{l}\text { Abandoned } \\
2003\end{array}$ & $\mathrm{~A}$ & $\begin{array}{l}\text { Abandoned } \\
2003\end{array}$ & A & $\begin{array}{l}\text { Abandoned } \\
2003\end{array}$ & A \\
\hline 2 & Pasture to forest & $\mathrm{AB}$ & $\begin{array}{l}\text { Abandoned } \\
\text { fields to forest }\end{array}$ & A & Pasture to forest & B & $\begin{array}{l}\text { Cultivated to } \\
\text { forest }\end{array}$ & A & Pasture to forest & B \\
\hline 3 & $\begin{array}{l}\text { Cultivated to } \\
\text { forest }\end{array}$ & $\mathrm{B}$ & $\begin{array}{l}\text { Cultivated to } \\
\text { forest }\end{array}$ & B & $\begin{array}{l}\text { Residential/ } \\
\text { commercial } \\
\text { no change }\end{array}$ & $\mathrm{B}$ & Pasture to forest & $\mathrm{AB}$ & $\begin{array}{l}\text { Cultivated to } \\
\text { forest }\end{array}$ & $\mathrm{BC}$ \\
\hline 4 & $\begin{array}{l}\text { Abandoned } \\
\text { fields to forest }\end{array}$ & $\mathrm{BC}$ & $\begin{array}{l}\text { Abandoned } \\
2003\end{array}$ & B & $\begin{array}{l}\text { Pasture to } \\
\text { residential/ } \\
\text { commercial }\end{array}$ & $\mathrm{B}$ & $\begin{array}{l}\text { Forest to } \\
\text { residential/ } \\
\text { commercial }\end{array}$ & $\mathrm{BC}$ & $\begin{array}{l}\text { Residential/ } \\
\text { commercial } \\
\text { no change }\end{array}$ & $\mathrm{BC}$ \\
\hline 5 & $\begin{array}{l}\text { Residential/ } \\
\text { commercial } \\
\text { no change }\end{array}$ & $\mathrm{CD}$ & $\begin{array}{l}\text { Residential/ } \\
\text { commercial } \\
\text { no change }\end{array}$ & B & $\begin{array}{l}\text { Abandoned } \\
\text { fields to forest }\end{array}$ & $\mathrm{BC}$ & $\begin{array}{l}\text { Abandoned } \\
\text { fields to } \\
\text { residential/ } \\
\text { commercial }\end{array}$ & $\mathrm{CD}$ & $\begin{array}{l}\text { Pasture no } \\
\text { change }\end{array}$ & $\mathrm{BC}$ \\
\hline 6 & $\begin{array}{l}\text { Pasture to } \\
\text { residential/ } \\
\text { commercial }\end{array}$ & $\mathrm{CD}$ & $\begin{array}{l}\text { Pasture to } \\
\text { residential/ } \\
\text { commercial }\end{array}$ & B & $\begin{array}{l}\text { Abandoned } \\
\text { fields to } \\
\text { residential/ } \\
\text { commercial }\end{array}$ & $\mathrm{BC}$ & $\begin{array}{l}\text { Abandoned } \\
\text { fields to forest }\end{array}$ & $\mathrm{CD}$ & $\begin{array}{l}\text { Pasture to } \\
\text { residential/ } \\
\text { commercial }\end{array}$ & $\mathrm{BCD}$ \\
\hline 7 & $\begin{array}{l}\text { Abandoned } \\
\text { fields to } \\
\text { residential/ } \\
\text { commercial }\end{array}$ & $\mathrm{CD}$ & $\begin{array}{l}\text { Pasture no } \\
\text { change }\end{array}$ & B & $\begin{array}{l}\text { Cultivated to } \\
\text { forest }\end{array}$ & $\mathrm{BC}$ & $\begin{array}{l}\text { Pasture to } \\
\text { residential/ } \\
\text { commercial }\end{array}$ & $\mathrm{DE}$ & $\begin{array}{l}\text { Abandoned } \\
\text { fields to forest }\end{array}$ & $\mathrm{BCD}$ \\
\hline 8 & $\begin{array}{l}\text { Pasture no } \\
\text { change }\end{array}$ & $\mathrm{DE}$ & $\begin{array}{l}\text { Forest to } \\
\text { residential/ } \\
\text { commercial }\end{array}$ & B & $\begin{array}{l}\text { Pasture no } \\
\text { change }\end{array}$ & $\mathrm{BC}$ & $\begin{array}{l}\text { Residential/ } \\
\text { commercial } \\
\text { no change }\end{array}$ & DE & $\begin{array}{l}\text { Abandoned } \\
\text { fields to } \\
\text { residential/ } \\
\text { commercial }\end{array}$ & BCDE \\
\hline 9 & $\begin{array}{l}\text { Forest to } \\
\text { residential/ } \\
\text { commercial }\end{array}$ & $\mathrm{DE}$ & $\begin{array}{l}\text { Abandoned } \\
\text { fields to } \\
\text { residential/ } \\
\text { commercial }\end{array}$ & B & $\begin{array}{l}\text { Cultivated to } \\
\text { residential/ } \\
\text { commercial }\end{array}$ & $\mathrm{C}$ & $\begin{array}{l}\text { Cultivated to } \\
\text { residential/ } \\
\text { commercial }\end{array}$ & $\mathrm{DE}$ & $\begin{array}{l}\text { Cultivated to } \\
\text { residential/ } \\
\text { commercial }\end{array}$ & $\mathrm{CDE}$ \\
\hline 10 & $\begin{array}{l}\text { Cultivated to } \\
\text { residential/ } \\
\text { commercial }\end{array}$ & $\mathrm{EF}$ & $\begin{array}{r}\text { Forest no } \\
\text { change }\end{array}$ & $\mathrm{C}$ & $\begin{array}{l}\text { Forest to } \\
\text { residential/ } \\
\text { commercial }\end{array}$ & $\mathrm{C}$ & $\begin{array}{l}\text { Pasture no } \\
\text { change }\end{array}$ & DEF & $\begin{array}{l}\text { Cultivated no } \\
\text { change }\end{array}$ & DE \\
\hline 11 & $\begin{array}{r}\text { Forest no } \\
\text { change }\end{array}$ & $\mathrm{F}$ & $\begin{array}{l}\text { Cultivated to } \\
\text { residential/ } \\
\text { commercial }\end{array}$ & $\mathrm{C}$ & $\begin{array}{l}\text { Cultivated no } \\
\text { change }\end{array}$ & $\mathrm{D}$ & $\begin{array}{c}\text { Forest no } \\
\text { change }\end{array}$ & $\mathrm{EF}$ & $\begin{array}{l}\text { Forest to } \\
\text { residential/ } \\
\text { commercial }\end{array}$ & DE \\
\hline 12 & $\begin{array}{l}\text { Cultivated no } \\
\text { change }\end{array}$ & $\mathrm{F}$ & $\begin{array}{l}\text { Cultivated no } \\
\text { change }\end{array}$ & $\mathrm{D}$ & $\begin{array}{r}\text { Forest no } \\
\text { change }\end{array}$ & $\mathrm{D}$ & $\begin{array}{l}\text { Cultivated no } \\
\text { change }\end{array}$ & $\mathrm{F}$ & $\begin{array}{r}\text { Forest no } \\
\text { change }\end{array}$ & $\mathrm{E}$ \\
\hline
\end{tabular}

Results are for the four main target species and for all six target species combined. All comparisons were made using Wilcoxon rank sum tests. Capital letters indicate significantly difference groupings $(P<0.05)$

timing of woody plant invasions across the New England, USA landscape. The greatest incidence of invasion is in post-agricultural settings, i.e., fields that are currently abandoned or have reverted to forest. Areas developed for residential/commercial use, whether or not they have an agricultural history, have significantly lower invasives prevalence. Finally, areas that have not undergone a change in land-use since 1934-most notably stable forests and continuously cultivated fields-have the lowest incidence of woody plant invasions. This ordering suggests that LULC change patterns are important in both the promotion of and resistance to invasion. These results also raise an important question: how do certain land-use patterns create opportunities for invasion while others deter them?

Three of the four main target species (Celastrus orbiculatus, Lonicera morrowii and Rosa multiflora) 
Table 5 Invasive abundance for agricultural plots ranked by time of abandonment

\begin{tabular}{lllllllllll}
\hline $\begin{array}{l}\text { Abundance } \\
\text { rank }\end{array}$ & $\begin{array}{l}\text { All } \\
\text { species }\end{array}$ & & $\begin{array}{l}\text { Berberis } \\
\text { thunbergii }\end{array}$ & & $\begin{array}{l}\text { Celastrus } \\
\text { orbiculatus }\end{array}$ & & $\begin{array}{l}\text { Lonicera } \\
\text { morrowii }\end{array}$ & \multicolumn{2}{c}{$\begin{array}{l}\text { Rosa } \\
\text { multi-flora }\end{array}$} \\
\hline 1 & 2003 & A & 1951 & A & 2003 & A & 1991 & A & 2003 & A \\
2 & 1991 & AB & 1934 & AB & 1991 & AB & 2003 & AB & 1991 & AB \\
3 & 1951 & ABC & 1970 & BC & 1951 & BC & 1970 & AB & 1970 & BC \\
4 & 1970 & BC & 1991 & CD & 1970 & BC & 1951 & B & 1951 & C \\
5 & 1934 & C & 2003 & D & 1934 & C & 1934 & B & 1934 & C \\
\hline
\end{tabular}

All comparisons were made using Wilcoxon rank sum tests. Capital levels indicate significantly different groupings $(P<0.05)$

Table 6 Stepwise regression model results for invasive species abundance

\begin{tabular}{|c|c|c|c|c|c|}
\hline $\begin{array}{l}\text { Rank by deviance } \\
\text { explained }\end{array}$ & All species & $\begin{array}{l}\text { Berberis } \\
\text { thunbergii }\end{array}$ & $\begin{array}{l}\text { Celastrus } \\
\text { orbiculatus }\end{array}$ & Lonicera morrowii & Rosa multiflora \\
\hline 1 & $\begin{array}{l}\text { LULC change } \\
13.8 \%\end{array}$ & $\begin{array}{l}\text { Canopy closure } \\
19.1 \%\end{array}$ & $\begin{array}{l}\text { Canopy closure } \\
13.9 \%\end{array}$ & LULC change $17.3 \%$ & $\begin{array}{l}\text { Canopy closure } \\
12.1 \%\end{array}$ \\
\hline 2 & $\begin{array}{l}\text { Canopy closure } \\
13.5 \%\end{array}$ & $\begin{array}{l}\text { LULC change } \\
\quad 6.0 \%\end{array}$ & $\begin{array}{l}\text { LULC change } \\
\quad 9.6 \%\end{array}$ & Distance to edge $7.0 \%$ & $\begin{array}{l}\text { LULC change } \\
11.5 \%\end{array}$ \\
\hline 3 & Habitat class $5.9 \%$ & $\begin{array}{l}Y \text { (northing) } \\
\quad \text { coordinate } 5.6 \%\end{array}$ & $\begin{array}{l}\text { Distance to edge } \\
3.2 \%\end{array}$ & $\begin{array}{l}X \text { (easting) coordinate } \\
6.1 \%\end{array}$ & $\begin{array}{l}\text { 1934 LULC } \\
\text { features } 3.3 \%\end{array}$ \\
\hline 4 & $\begin{array}{l}\text { Distance to edge } \\
4.8 \%\end{array}$ & $\begin{array}{l}1951 \text { LULC } \\
\text { features } 2.2 \%\end{array}$ & $\begin{array}{l}1970 \text { LULC } \\
\text { features } 3.2 \%\end{array}$ & $\begin{array}{l}\text { Heavily managed plots } \\
3.8 \%\end{array}$ & $\begin{array}{l}\text { Distance to edge } \\
3.2 \%\end{array}$ \\
\hline 5 & $\begin{array}{l}\text { Heavily managed } \\
\text { plots } 3.2 \%\end{array}$ & $\begin{array}{l}1934 \text { LULC } \\
\text { features } 1.9 \%\end{array}$ & $\begin{array}{l}Y \text { (northing) } \\
\quad \text { coordinate } 3.1 \%\end{array}$ & $\begin{array}{l}\text { Soil type \#14 (penwood } \\
\text { loamy sand) } 2.3 \%\end{array}$ & $\begin{array}{l}Y \text { (northing) } \\
\text { coordinate } 3.0 \%\end{array}$ \\
\hline $\begin{array}{l}\text { Variables in } \\
\text { model }\end{array}$ & 24 & 22 & 20 & 19 & 17 \\
\hline Model $R^{2}$ & 0.55 & 0.46 & 0.41 & 0.50 & 0.42 \\
\hline
\end{tabular}

had levels of abundance that were highest in plots abandoned as of 2003 or 1991, so that their abundance generally declined with time since agricultural abandonment. Berberis thunbergii provides a clear exception to this pattern. Its highest levels of abundance were associated with abandonment during the 1934 and 1951 time steps, and its abundance declined significantly with more recent abandonment. This pattern probably stems from $B$. thunbergii's high degree of shade tolerance (Silander and Klepeis 1999), and its low mortality rate once established (Ehrenfeld 1999). In contrast to the other species, B. thunbergii is a long-term abandonment specialist; it is capable of spreading and then surviving for many years through canopy closure. This finding is consistent with and supports the findings in a recent study in a Massachusetts secondary forest landscape, in which Berberis was found to have invaded more extensively during an earlier period of greater agricultural abandonment, and less so in recent years (DeGasperis and Motzkin 2007).
The strong association of invasive species abundance with canopy closure suggests that light and its changing availability on abandoned land is a key factor in the sorting of invasive species during the course of succession. All of our target species showed a marked drop in abundance between the third (51-75\%) and fourth (76-100\%) canopy closure categories, including B. thunbergii. However, $B$. thunbergii was the least negatively affected by decreasing light levels; this helps to explain its abundance in older post-agricultural forests (Silander and Klepeis 1999).

That the most open canopy closure category $(0-25 \%)$ had the lowest levels of invasive abundance can be explained by an association with intensive management. Over 90\% (156/173) of the sample plots with full light conditions were situated in actively managed fields or residential/commercial settings. In such settings, human interventions such as plowing, mowing, landscaping and paving, generally 
preclude naturalization by woody plants. In contrast, an absence of human intervention combined with high to moderate light levels, as is characteristic of vegetation edges and abandoned fields, is likely to create favorable habitat for woody invasive plants and the agents of their dispersal.

The regression modeling results reinforce the importance of both current and past land-use history in driving invasion dynamics. Land-use change and canopy closure (which is itself strongly related to historical land use and the process of succession, as well as to current land use) were the most important predictors in the stepwise regression models. Distance to a vegetation edge was the next most consistent predictor, and edges as defined in this study (sharp transitions from full light/open canopy to continuous/ closed canopy) were generally due to human disturbance. Edges may be related to woody invasive distributions in several ways: first, vegetation edges are characterized by intermediate light levels; second, edges are generally not mowed or herbicided; third, structural complexity at vegetation edges may attract seed dispersers; and finally, vegetation edges can act as traps for wind-driven seeds and nutrients (Weathers et al. 2001; Williams-Linera 1990).

Perhaps the most intriguing implications of this study come from looking at the invasion processes of individual species in the context of changing land-use trends. In particular, B. thunbergii invasions appear strongly connected to a pattern of agricultural abandonment, as was also found by DeGasperis and Motzkin (2007) in an undeveloped Massachusetts forest, despite the ongoing land use change in our study region that has in many areas overlain the agricultural abandonment with subsequent residential development. In this region, pressure to develop land for residential/commercial purposes is on the rise, while agricultural abandonment has become unusual. We conclude that unless this trend changes dramatically, new B. thunbergii infestations should be less likely, though its shade tolerance will probably allow this species to persist in the landscape indefinitely.

Celastrus orbiculatus, in contrast, has the weakest association with past agricultural land use, and seems rather to thrive in recently disturbed and edge habitats that are prevalent in the contemporary landscape. The invasion success of $C$. orbiculatus has been attributed to the fact that it is widely dispersed by birds and humans, it can tolerate a wide range of edaphic conditions, it has extensive powers of photosynthetic acclimation, it grows quickly towards light and it can climb on all manner of supports (Leicht-Young et al. 2007; Silveri et al. 2001). These qualities have enabled $C$. orbiculatus to exploit present land-use trends including forest fragmentation and residential/ commercial development.

This study lends further support to previous conclusions that large temperate forest blocks appear to resist woody plant invasions well. Current land-use trends, however, present cause for concern about the future even in these persistent landscape elements. A forest's resistance to invasion probably stems from two main factors: the deep shade created by mature trees (as evidenced by the canopy closure and regression modeling results) and the buffering effect of its size, which serves to isolate interior portions of the forest from invasive propagules. If present land-use trends continue, the increased fragmentation of forest parcels in New England may allow edge adapted invasive plants (e.g., C. orbiculatus) to get a deeper foothold into forest blocks, creating propagule pressure where it had previously been absent. Eventually, this could allow woody invaders to take advantage of disturbances (such as logging) within the major forest blocks of the region (Silveri et al. 2001). Our findings suggest two basic messages related to land management in the region. First, land management to reduce invasive abundance should focus primarily on maintaining the integrity of forest blocks, and also on species, like $C$. orbiculatus, best suited to take advantage of ongoing land-use trends. Second, parcels that have had a history of agricultural use, regardless of their current status, deserve special attention as likely sites for exotic species to colonize and thrive.

Acknowledgments We thank Daniel Civco, Les Mehrhoff, Robin Chazdon and Stacey Leicht-Young for their assistance and guidance, and an anonymous reviewer for helpful comments. We gratefully acknowledge grant support from United States Department of Agriculture for the Invasive Plant Atlas of New England (Silander), the Connecticut College Space Grant Consortium (Mosher), and the National Science Foundation Graduate Research Fellowship Program and the University of California Davis Department of Plant Sciences (Latimer).

Open Access This article is distributed under the terms of the Creative Commons Attribution Noncommercial License which permits any noncommercial use, distribution, and reproduction in any medium, provided the original author(s) and source are credited. 


\section{References}

Al-tahir R, Ali A (2004) Assessing land cover changes in the coastal zone using aerial photography. Surv Land Inf Sci 63:107-112

Aragon R, Morales JM (2003) Species composition and invasion in NW Argentinian secondary forests: effects of land use history, environment and landscape. J Veg Sci 14:195-204

Bartuszevige AM, Gorchov DL, Raab L (2006) The relative importance of landscape and community features in the invasion of an exotic shrub in a fragmented landscape. Ecography 29:213-222

Bellemare J, Motzkin G, Foster DR (2002) Legacies of the agricultural past in the forested present: an assessment of the historical land-use effects on rich mesic forests. J Biogeogr 29:1401-1420

CLEAR (2004) Connecticut's changing landscape. University of Connecticut, Storrs

Cronon W (1983) Changes in the land. Indians, colonists and the ecology of New England. Hill and Wang, New York

De Blois S, Domon G, Bouchard A (2002) Landscape issues in plant ecology. Ecography 25:244-256

DeGasperis BG, Motzkin G (2007) Windows of opportunity: historical and ecological controls on Berberis thunbergii invasions. Ecology 88:3115-3125. doi:10.1890/06-2014.1

Donohue K, Foster DR, Motzkin G (2000) Effects of the past and the present on species distribution: land-use history and the demography of wintergreen. J Ecol 88:303-316. doi:10.1046/j.1365-2745.2000.00441.x

Dupre C, Ehrlen J (2002) Habitat configuration, species traits and plant distributions. J Ecol 90:796-805. doi:10.1046/ j.1365-2745.2002.00717.x

Ehrenfeld J (1999) Structure and dynamics of populations of Japanese barberry (Berberis thunbergii DC). J Torrey Bot Soc 124:210-215. doi:10.2307/2996586

Foster DR (1992) Land-use history (1730-1990) and vegetation dynamics in Central New England, USA. J Ecol 80:753-772. doi:10.2307/2260864

Foster DR, Motzkin G, Slater B (1998) Land-use history as long-term broad-scale disturbance: regional forest dynamics in central New England. Ecosystems (NY, Print) 1:96-119. doi:10.1007/s100219900008

Gerhardt F, Foster DR (2002) Physiographical and historical effects on forest vegetation in central New England, USA. J Biogeogr 29:1421-1437. doi:10.1046/j.1365-2699.2002. 00763.x

Hall B, Motzkin G, Foster DR, Syfert M, Burk J (2002) Three hundred years of forest and land-use change in Massachusetts, USA. J Biogeogr 29:1319-1335. doi:10.1046/j.13652699.2002.00790.x

Herron PM, Martine CT, Latimer AM, Leicht-Young SA (2007) Invasive plants and their ecological strategies: prediction and explanation of woody plant invasion in New England. Divers Distrib 13:633-644

Hobbs RJ (2000) Land-use changes and invasion. In: Mooney HA, Hobbs RJ (eds) Invasive species in a changing world. Island Press, Washington, DC, pp 55-64

Hobbs RJ (2001) Synergisms among habitat fragmentation, livestock grazing, and biotic invasions in Southwestern
Australia. Conserv Biol 15:1522-1528. doi:10.1046/ j.1523-1739.2001.01092.x

Kulmatiski A, Beard KH, Stark JM (2006) Soil history as a primary control on plant invasion in abandoned agricultural fields. J Appl Ecol 43:868-876. doi:10.1111/j.1365-2664. 2006.01192.x

Latimer AM, Banerjee S, Sang H, Mosher ES, Silander Jr JA (2009) Hierarchical models facilitate spatial analysis of large data sets: a case study on invasive plant species in the northeastern United States. Ecol Lett 12 (in press)

Leicht-Young SA, Silander JA, Latimer AM (2007) Comparative performance of invasive and native Celastrus species across environmental gradients. Oecologia 154: 273-282. doi:10.1007/s00442-007-0839-3

Lundgren MR, Small CJ, Dreyer GD (2004) Influence of land use and site characteristics on invasive plant abundance in the Quinebaug Highlands of southern New England. Northeast Nat 11:313-332. doi:10.1656/1092-6194(2004) 011[0313:IOLUAS]2.0.CO;2

Mack RN (2000) Cultivation fosters plant naturalization by reducing environmental stochasticity. Biol Invasions 2:111-122. doi:10.1023/A:1010088422771

Mehrhoff LJ, Silander JA, Leicht SA, Mosher ES, Tabak NM (2003) IPANE: the invasive plant atlas of New England. Department of Ecology and Evolutionary Biology, University of Connecticut, Storrs. Retrieved from www.ipane. org on June 2007

Meiners SJ, Pickett STA, Cadenasso ML (2002) Exotic plant invasions over 40 years of old field successions: community patterns and associations. Ecography 25:215-223. doi:10.1034/j.1600-0587.2002.250209.x

Motzkin G, Wilson P, Foster DR, Allen A (1999) Vegetation patterns in heterogeneous landscapes: the importance of history and environment. J Veg Sci 20:903-920. doi: 10.2307/3237315

Pascarella JB, Aide TM, Serrano MI, Zimmerman JK (2000) Land-use history and forest regeneration in the Cayey mountains of Puerto Rico. Ecosystems (NY, Print) 3:217228. doi:10.1007/s100210000021

Rangel TFLVB, Diniz-Filho JAF, Bini LM (2006) Towards an integrated computational tool for spatial analysis in macroecology and biogeography. Glob Ecol Biogeogr 15:321-327. doi:10.1111/j.1466-822X.2006.00237.x

Richardson DM, Pysek P, Rejmanek M, Barbour MG, Panetta FD, West CJ (2000) Naturalization and invasion of alien plants: concepts and definitions. Divers Distrib 6:93-107. doi:10.1046/j.1472-4642.2000.00083.x

Silander JA, Klepeis DM (1999) The invasion ecology of Japanese barberry (Berberis thunbergii) in the New England landscape. Biol Invasions 1:189-201. doi:10.1023/ A:1010024202294

Silveri A, Dunwiddie PW, Michaels HJ (2001) Logging and edaphic factors in the invasion of an Asian woody vine in a mesic North American forest. Biol Invasions 3:379-389. doi:10.1023/A:1015898818452

Singleton R, Gardescu S, Marks PL, Geber MA (2001) Forest herb colonization of postagricultural forests in central New York State. J Ecol 89:325-338. doi:10.1046/j.13652745.2001.00554.x

Snedecor GW, Cochran WG (1989) Statistical methods. Iowa State University Press, Ames 
Sohl TL, Gallant AL, Loveland TR (2004) The characteristics and interpretability of land surface change and implications for project design. Photogramm Eng Remote Sens 70:439-448

Thorson RM (2002) Stone by stone. Walker \& Company, New York

Venables WN, Ripley BD (2002) Modern applied statistics with S. Springer-Verlag, New York

Verheyen K, Guntenspergen GR, Biesbrouck B, Hermy M (2003a) An integrated analysis of the effect of past land use on forest herb colonization at the landscape scale. $\mathrm{J}$ Ecol 91:731-742. doi:10.1046/j.1365-2745.2003.00807.x

Verheyen K, Honnay O, Motzkin G, Hermy M, Foster DR (2003b) Response of forest plant species to land-use change: a life-history trait-based approach. J Ecol 91:563577. doi:10.1046/j.1365-2745.2003.00789.x
Vila M, Burriel J, Pino J, Chamizo J, Llach E, Porterias M, Vives M (2003) Association between Opuntia species invasion and changes in land-cover in the Mediterranean region. Glob Change Biol 9:1234-1239. doi:10.1046/j.13652486.2003.00652.x

Weathers KC, Cadenasso ML, Pickett STA (2001) Forest edges as nutrient and pollutant concentrators: potential synergisms between fragmentation, forest canopies, and the atmosphere. Conserv Biol 15:1506-1514. doi:10.1046/ j.1523-1739.2001.01090.x

Williams-Linera G (1990) Vegetation structure and environmental conditions of forest edges in Panama. $\mathrm{J}$ Ecol 78:356-373. doi: $10.2307 / 2261117$

With KA (2002) The landscape ecology of invasive spread. Conserv Biol 16:1192-1203. doi:10.1046/j.1523-1739. 2002.01064.x 